\title{
Influence of Insulin-Like Growth Factor I and Nutrition During Phases of Postnatal Growth in Very Preterm Infants
}

\author{
INGRID HANSEN-PUPP, CHATARINA LÖFQVIST, STAFFAN POLBERGER, AIMON NIKLASSON, VINETA FELLMAN, \\ ANN HELLSTRÖM, AND DAVID LEY
}

\begin{abstract}
Department of Pediatrics, [I.H.-P., S.P., V.F., D.L.], Lund University, 22185 Lund, Sweden; Department of Ophthalmology [C.L., A.H.], Department of Pediatrics [A.N.], Gothenburg University, 40530 Göteborg, Sweden; Department of Pediatrics, [V.F.], University of Helsinki, 00014 Helsinki, Finland
\end{abstract}

\begin{abstract}
Pronounced growth restriction (GR) occurs after very preterm birth. The interaction between IGF-I, nutritional intake, and growth was evaluated prospectively in 64 infants with a mean (SD) GA of 25.7 (1.9) wk. Blood sampling of IGF-I and measurements of weight, length, and head circumference were performed weekly until discharge. Daily calculation of nutritional intake was performed. Standard deviation scores (SDSs) for growth parameters defined two growth phases: GR phase (birth until lowest SDS) and catch-up (CU) phase (lowest SDS until 35 gestational weeks). IGF-I concentrations during the first postnatal weeks were low and increased at $30 \mathrm{wk}$ GA, irrespective of GA at birth, coinciding with initiation of CU growth. Concentrations of IGF-I were positively associated with change in weight SDS during the GR phase, $p=0.001$ and CU phase, $p=$ $0.004-0.027$. Protein and energy intake were not associated with change in SDS weight during the GR phase as opposed to the CU phase ( $p<0.001$, respectively). Nutritional intake did not correlate to concentrations of IGF-I before $30 \mathrm{wk}$ GA. IGF-I is associated with growth at an earlier postnatal age than nutrient intake and the effect of nutrition on levels of IGF-I may be restricted to the period of established CU growth. (Pediatr Res 69: 448-453, 2011)
\end{abstract}

$\mathrm{T}$ The maximum growth rate of the fetus is reached in the middle of pregnancy, where it is approximately three times higher than at term (1). Fetal growth rate is to a large extent determined by placental capacity of delivering nutrients to the fetus, whereas genetic influence seems to play a less important role. Placental function depends on the maternal nutritional state and the intrauterine endocrine environment. At preterm birth, the fetal-placental interaction is interrupted, which has an impact on continued extrauterine growth capacity. Postnatal growth retardation occurs almost inevitably after preterm birth and has been associated with decreased brain volumes and impaired neurodevelopmental outcome $(2,3)$. Although attempts are made to optimize postnatal nutritional intakes in preterm infants, these are still commonly subopti-

\footnotetext{
Received August 31, 2010; accepted November 20, 2010.

Correspondence: Ingrid Hansen-Pupp, M.D., Ph.D., Division of Pediatrics, Department of Clinical Sciences, Lund University Hospital, 22185 Lund, Sweden; e-mail: ingrid.pupp@skane.se

Supported by the Swedish Medical Research Council (grant 14940, 4732, 20144-01-3, and 21144-01-3), Government grants (ALFGB2770), the Skåne Council Foundation for Research and Development, and the Linnéa and Josef Carlsson Foundation.

The application to prevent ROP by means of administering IGF-I is covered by patents and patent applications owned by Children's Medical Center Corporation, Boston, MA and Premacure AB, Uppsala, Sweden. IH-P, CL, AH, and DL own shares in a company controlling Premacure AB. Remaining authors have nothing to declare.
}

mal according to intrauterine requirements (4). Increased postnatal nutritional intake has been shown to improve growth rate in very LBW infants (5), although a recent study could not demonstrate any apparent effect of hyperalimentation on subsequent postnatal growth in very preterm infants (6).

IGF-I is an important fetal growth factor, which is essential for the developing brain (7). Concentrations of fetal IGF-I are closely related to placental transfer of glucose where fetal glucose increases insulin secretion, which in turn stimulates fetal IGF-I production (8). Fetal levels of IGF-I may also be regulated by an interaction at the feto-maternal placental interface (9). The disruption of placental nutrient supply after birth is followed by a rapid decrease in postnatal levels of IGF-I, suggesting a low endogenous production (10). While term infants restore their IGF-I levels within the first postnatal weeks, very preterm infants continue to have low levels during several weeks (11). Both IGF-I and IGF binding protein-3 (IGFBP-3) are related to early postnatal growth in preterm infants $(12,13)$. Persisting low postnatal levels of IGF-I have been associated with impaired longitudinal weight gain, as well as retinopathy of prematurity in preterm infants $(14,15)$.

We hypothesized that the interaction between circulatory IGF-I concentrations, postnatal growth and nutrition would be different during the early growth restriction (GR) phase after birth compared with that during the later catch-up (CU) phase. This paper describes a prospective clinical study in very preterm infants, where weekly growth measurements and analyses of IGF-I with daily registrations of nutritional intake were related to growth during phases of GR and CU.

\section{METHODS}

Study population. The study was a prospective longitudinal cohort study in infants born at Lund University Hospital between January 2005 and May 2007. The study was approved by the Regional Ethical Review Board, Lund, Sweden. Pregnant women admitted to Lund University Hospital, with a risk of delivery before $31 \mathrm{wk}$ were identified and included before delivery after written informed consent from both parents. All pregnancies were dated by ultrasound at 17-18 gestational weeks (GW) (16). Inclusion criteria were a GA $<31$ wk at birth, antenatal informed consent from both parents, and absence of major congenital anomalies. Sixty-four infants were enrolled in the study, out of a total of 173 infants born before $31 \mathrm{GW}$ in Lund during the study period. Twelve infants did not complete the study, 9 infants died and

Abbreviations: CU, catch-up; GW, gestational week; GR, growth restriction; HC, head circumference; PMA, postmenstrual age; SDS, standard deviation score 
the parents of 3 infants declined continued participation, leaving 52 eligible infants for evaluation.

Blood sampling and quantitative analysis of IGF-I. Blood sampling for analysis of IGF-I and IGFBP-3 was performed before enteral feeding at $72 \mathrm{~h}$ and at $7 \mathrm{~d}$ postnatal age and thereafter weekly (on a predefined weekday) until at least a GA of $35 \mathrm{wk}$ from an umbilical or peripheral arterial catheter and thereafter by venous puncture.

After centrifugation, serum samples were stored at $-80^{\circ} \mathrm{C}$ until assayed. The IGF-I samples were diluted 1:50, and the IGF-I concentrations were analyzed using IGFBP-blocked RIA (Mediagnost GmbH, Tübingen, Germany). The intra-assay coefficients of variation for IGF-I were 18, 11, and 7\% at concentrations of 9,33 , and $179 \mu \mathrm{g} / \mathrm{L}$. All samples were analyzed within the same assay. The method has been described in detail previously (17). All values of IGF-I were omitted for further evaluation, if the infant had received transfusion of fresh frozen plasma during the same day and before sampling of IGF-I was performed.

Growth measurements. Standardized measurements of weight, length, and head circumference $(\mathrm{HC})$ were performed within the first $24 \mathrm{~h}$ after birth and then weekly on the same weekday as blood sampling for IGF-I and continued until discharge. The majority of the growth measurements were performed by one examiner (IH-P). Weight was measured on a digital scale (Tanita TL-150MA, Tanita Corporation, Tokyo, Japan). Crown to heel length was measured using a portable length scale instrument with increments in millimeters developed at the NICU in Lund enabling measurements within the incubator as on the nursing table. $\mathrm{HC}$ was measured in the maximum fronto-occipital plane using an individual nonextensible plastic-coated tape with increments in millimeters. Infants with posthemorrhagic hydrocephalus $(n=2)$ were not included in analyzes of HC data.

Standard deviation score (SDS) was calculated for all measurements of each respective growth parameter. SDS indicates how many SD an observation is above or below the mean of a reference population. SDS length and SDS HC were computed from a gender-specific growth reference in a Swedish population (18), whereas weight SDS was calculated from an intrauterine growth curve based on a ultrasonically estimated fetal weights in Scandinavia (16). Lowest SDS (nadir) for each respective growth parameter was defined as the lowest SDS occurring after birth, which was followed by gradually increasing SDS.

The time period from birth until lowest SDS was defined as phase of GR, whereas the time period occurring from lowest SDS until $35 \mathrm{GW}$ was defined as phase of CU. Degree of postnatal GR ( $\triangle$ SDS GR) was defined as the difference between lowest SDS and SDS at birth for each respective growth parameter. Degree of catch-up growth ( $\triangle$ SDS CU) was defined as the difference between SDS at a GA of 35 wk and lowest SDS.

Nutritional regime and calculation of intake. Parenteral nutrition was initiated within the first hour after birth, with infusion of amino acids (Vaminolac) at a concentration of $0.98 \mathrm{~g} / 100 \mathrm{~mL}$ and glucose $106 \mathrm{mg} / \mathrm{mL}$. After $3 \mathrm{~d}$, concentration of amino acids was increased to $1.96 \mathrm{~g} / 100 \mathrm{~mL}$. On the second postnatal day, i.v. fat was added (Intralipid $200 \mathrm{mg} / \mathrm{mL}$ ), with a starting dose of $0.5 \mathrm{~g} / \mathrm{kg} / \mathrm{d}$ followed by a gradual increase up to $2 \mathrm{~g} / \mathrm{kg} / \mathrm{d}$. Concomitant minimal enteral feeding was started within $3 \mathrm{~h}$ of age and administered every $2-3 \mathrm{~h}$ with $1-2 \mathrm{~mL} / \mathrm{meal}$ and was thereafter gradually increased. Previously frozen and pasteurized donor breast milk was used until the mother could provide own breast milk.

All administered breast milk was analyzed weekly for protein $(\mathrm{g} / 100 \mathrm{~mL})$ and caloric content $(\mathrm{kcal} / 100 \mathrm{~mL})$ with the Milko Scan $104 \mathrm{IR}$ analyzer (A/S Foss Electric, Denmark). The milk sample was analyzed from a 10-mL representative sample in a well-mixed $24 \mathrm{~h}$ collection, for the first time $7 \mathrm{~d}$ after delivery and then weekly.

Nutritional intake aimed at a protein intake of $3.5 \mathrm{~g} / \mathrm{kg} / \mathrm{d}$ and an energy intake of $120 \mathrm{kcal} / \mathrm{kg} / \mathrm{d}$ as soon as possible. Supplemental individualized fortification of breast milk with a commercial human milk fortifier was provided based on analysis of protein and caloric intakes. Prospective daily calculation of enteral, parenteral, and total nutritional intake of protein $(\mathrm{g})$ and energy (kcal) was performed until at least $35 \mathrm{GW}$.

Accumulated daily protein and caloric intake were calculated during the respective phases of $\mathrm{GR}$ and $\mathrm{CU}$, for each respective growth parameter. Adjustment was performed for weight $(\mathrm{g})$ at the beginning of each time period [i.e. birth weight (BW) for phase of GR and weight at lowest SDS for phase of $\mathrm{CU}]$ and for duration in weeks of the respective phase for each respective growth parameter.

Clinical data. Treatment with hydrocortisone $(1-2 \mathrm{mg} / \mathrm{kg} / \mathrm{dose})$ was initiated due to resistant arterial hypotension or hypoglycemia. Betamethasone was administered due to severe lung disease, at a minimum postnatal age of $10-14 \mathrm{~d}(0.1 \mathrm{mg} / \mathrm{kg} /$ dose initially, with gradually tapering of dose). Insulin treatment was started when plasma glucose concentrations were persistent above $10-12 \mathrm{mmol} / \mathrm{L}$ and no reduction of glucose intake was possible.
Daily administered dose of hydrocortisone $(\mathrm{mg} / \mathrm{kg})$, betamethasone $(\mathrm{mg} / \mathrm{kg}$ ), insulin $(\mathrm{E} / \mathrm{kg})$, and fresh frozen plasma $(\mathrm{mL})$ was registered prospectively until discharge, and the accumulated dose was calculated during phase of GR and $\mathrm{CU}$ for each respective growth parameter.

Statistical analyses. Statistical analyses were performed using the Statistical Package for Social Sciences software for Microsoft Windows (IBM Acquires SPSS Inc, Chicago, IL).

Correlations were assessed using Pearson correlation, except for correlations between SDS for each growth parameter and accumulated dose of steroids or insulin when Spearman rank correlations were used. Adjustment for other variables was performed by using multiple linear regression analysis. The contribution of IGF-I and nutritional intake to change in SDS during phase of GR and CU for each respective growth parameter was assessed using multivariate stepwise analysis with protein and energy intake evaluated in separate models. Variables included in models for the phase of GR were GA, gender, birth weight, duration of GR phase (wk), mean IGF-I ( $\mu \mathrm{g} / \mathrm{L})$, accumulated protein $(\mathrm{g})$ and energy intake $(\mathrm{kcal})$, accumulated dose of hydrocortisone and betamethasone $(\mathrm{mg} / \mathrm{kg})$, and accumulated dose of insulin $(\mathrm{E} / \mathrm{kg})$ during phase of GR. Variables included in models for the phase of CU were GA, gender, weight at lowest SDS, duration of CU phase (wk), mean IGF-I $(\mu \mathrm{g} / \mathrm{L})$, accumulated protein $(\mathrm{g})$ and energy intake $(\mathrm{kcal})$, accumulated dose of hydrocortisone and betamethasone $(\mathrm{mg} / \mathrm{kg})$ during phase of $\mathrm{CU}$.

\section{RESULTS}

The neonatal characteristics of the study population are presented in Table 1.

Characteristics of phases of postnatal growth. Table 2 and Figure 1 describe mean values and longitudinal changes in SDS for weight, length, and HC. Longitudinal development of SDS from birth until a GA of $35 \mathrm{wk}$ displayed a characteristic pattern for all growth parameters with a pronounced decrease in SDS after birth with a lowest SDS occurring approximately at a GA of 30 wk independently of GA at birth.

Age in postnatal weeks at lowest SDS for weight, length, and HC correlated negatively with GA at birth, $r=-0.68$, $p<0.001 ; r=-0.68, p<0.001$; and $r=-0.74, p<0.001$,

Table 1. Neonatal characteristics of the study population $(\mathrm{N}=64)$

$\begin{array}{lc}\text { GA }(w k), \text { mean }(\mathrm{SD}) & 25.7(1.9) \\ \text { Birth weight }(\mathrm{g}), \text { mean }(\mathrm{SD}) & 852(276) \\ \text { Birth weight }<-2 \mathrm{SD}(\mathrm{SGA}), N(\%) & 16(25) \\ \text { Antenatal betamethasone treatment, } N(\%) & 63(98) \\ \text { Male gender, } N(\%) & 33(52) \\ \text { Betamethasone treatment during GR/CU phase } & 16(25) / 10(16)\end{array}$

Betamethasone treatment during GR/CU phase for weight, $N(\%)$

Hydrocortisone treatment during GR/CU phase for weight, $N(\%)$

Insuline treatment during $\mathrm{GR} / \mathrm{CU}$ phase for weight, $N(\%)$

GA (wk) at discharge, mean (SD)

$13(20) / 3(5)$

$9(14) / 0(0)$

$38.2(2.0)$

SGA, small-for-GA.

Table 2. Characteristics of SDS for weight, length, and HC from birth until a PMA of 40 wk

\begin{tabular}{lccc}
\hline \multicolumn{1}{c}{ SDS } & Weight & Length & $\begin{array}{c}\text { Head } \\
\text { circumference }\end{array}$ \\
\hline SDS at birth & $-1.1(1.3)$ & $-1.6(1.7)$ & $-0.3(1.4)$ \\
SDS at a PMA of 35 wk & $-1.6(1.1)$ & $-2.8(1.4)$ & $-1.3(0.7)$ \\
SDS at a PMA of 40 wk & $-1.1(1.0)$ & $-1.7(1.4)$ & $-1.1(1.0)$ \\
Lowest SDS & $-2,8(0.8)$ & $-3.5(1.5)$ & $-2.3(1.3)$ \\
PMA (weeks) at lowest SDS & $29.8(1.5)$ & $31.5(1.6)$ & $29.6(1.6)$ \\
Postnatal age (weeks)at & $3.8(1.6)$ & $5.5(2.1)$ & $3.6(2.2)$ \\
$\quad$ lowest SDS & & & \\
Maximum decrease in SDS & $-1.8(0.7)$ & $-2.1(0.9)$ & $-2.1(0.9)$ \\
\hline
\end{tabular}

PMA, postmenstrual age. 

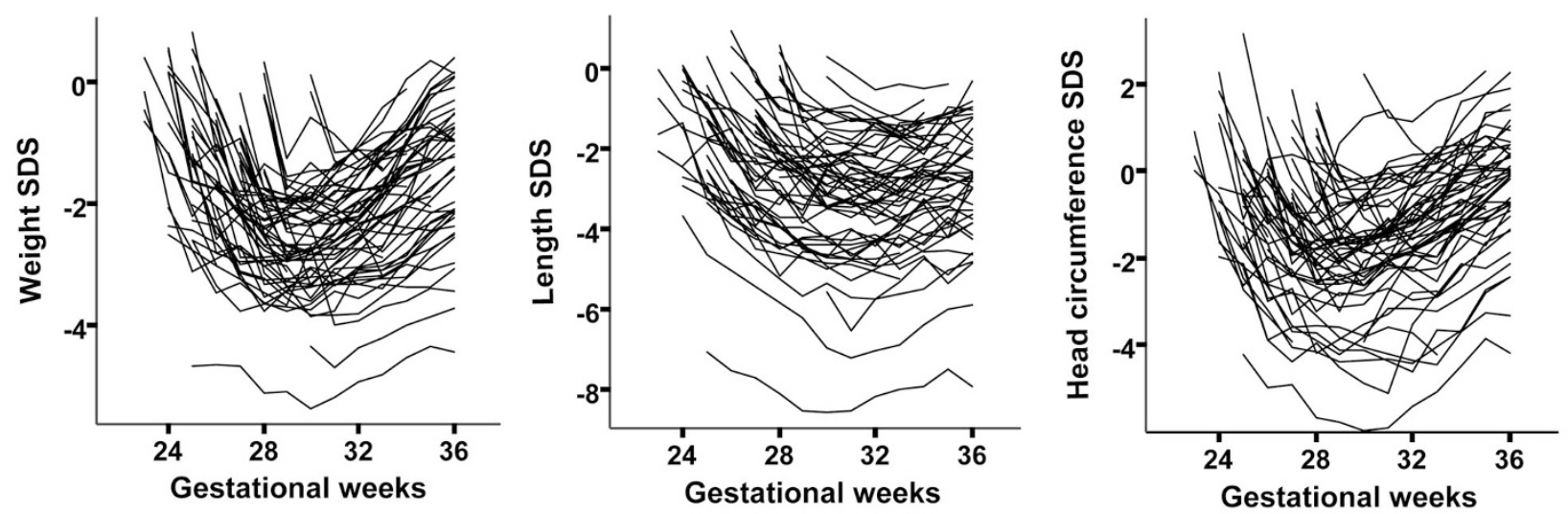

Figure 1. Individual longitudinal changes in SD scores for weight, length, and $\mathrm{HC}$ in relation to $\mathrm{GA}(n=52)$.

respectively, i.e. lowest SDS occurred at a higher postnatal age in the most immature infants.

$\triangle$ SDS GR for weight, length, and HC correlated positively with GA in days $r=0.60 p<0.001, r=0.65 p<0.001$, and $r=0.64 p<0.001$, respectively, i.e. the most immature infants had the most pronounced degree of GR. No corresponding correlation was observed between $\triangle \mathrm{SDS} \mathrm{CU}$ and GA at birth.

$\Delta$ SDS GR for weight, length, and HC correlated negatively with corresponding SDS at birth, $r=-0.73, p<0.001 ; r=$ $-0.32, p=0.019$; and $r=-0.40, p=0.004$, i.e. infants growth restricted at birth had a less pronounced postnatal decrease in SDS than non-growth-restricted infants. No corresponding correlations were seen between $\triangle \mathrm{SDS} \mathrm{CU}$ and SDS at birth.

There were no gender differences in $\Delta$ SDS GR for any of the growth parameters. Male infants had a better CU in weight SDS than female infants $\Delta$ SDS CU 1.4 (0.54) versus $1.0(0.6)$, $p=0.029$, whereas $\Delta$ SDS CU for length and $\mathrm{HC}$ did not differ according to gender.

$\triangle$ SDS GR for weight, length, and HC correlated negatively with accumulated dose of betamethasone $(\mathrm{mg} / \mathrm{kg})$ during phase of GR, $r=-0.38, p=0.005 ; r=-0.50, p<0.001$; and $r=-0.54, p<0.001$. $\Delta$ SDS GR for length and HC correlated negatively with accumulated dose of hydrocortisone $(\mathrm{mg} / \mathrm{kg})$ during phase of GR, $r=-0.32 ; p=0.019$ and $r=-0.54 ; p<0.001$. These correlations disappeared after adjustment for GA at birth. Accumulated dose of hydrocortisone or betamethasone $(\mathrm{mg} / \mathrm{kg})$ during phase of CU did not correlate with $\triangle \mathrm{SDS} C \mathrm{CU}$. No correlation was observed between accumulated dose of insulin $(\mathrm{E} / \mathrm{kg})$ and $\Delta \mathrm{SDS}$ GR. No infants received insulin during phase of CU.

IGF-I longitudinal changes and relationships to clinical variables. Longitudinal changes in IGF-I $(\mu \mathrm{g} / \mathrm{L})$ from birth until $35 \mathrm{GW}$ are shown in Figure 2. Mean (95\% CI) concentrations of IGF-I in relation to GA display a pattern with a very slow increase in concentrations, until an achieved postmenstrual age (PMA) of $\sim 30 \mathrm{wk}$ followed by a clear increase thereafter.

Mean concentrations of IGF-I during phase of $\mathrm{CU}$ for weight, length, and $\mathrm{HC}$ correlated positively with GA in days

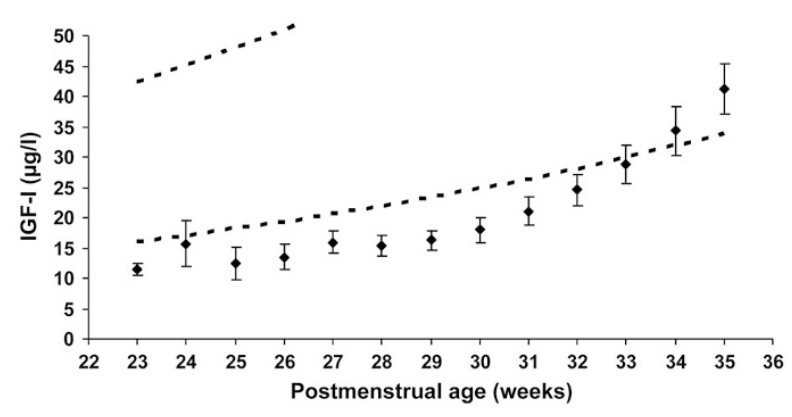

Figure 2. Mean $(95 \% \mathrm{CI})$ concentrations of IGF-I $(\mu \mathrm{g} / \mathrm{L})$ from birth until 35 $\mathrm{GW}(n=52)$. Dashed lines represent $95 \%$ CI of fetal IGF-I during corresponding GW. Values for each postmenstrual week represent samples obtained at $\mathrm{GW}+0 \mathrm{~d}$ up to $\mathrm{GW}+6 \mathrm{~d}$.

at birth $r=0.4, p=0.005 ; r=0.32, p=0.031$; and $r=0.32$, $p=0.029$, respectively. No corresponding correlation was seen during phase of GR.

Lower SDS weight at birth was associated with lower mean IGF-I concentrations during phase of GR for weight $r=0.46$, $p<0.001$ and during phase of $\mathrm{CU}$ for weight, $r=0.42, p=$ 0.003 .

Mean concentrations of IGF-I during phase of GR and CU for weight, length, and HC did not differ according to gender and did not correlate with accumulated intake of hydrocortisone, betamethasone $(\mathrm{mg} / \mathrm{kg})$, or insulin $(\mathrm{E} / \mathrm{kg})$ during the respective phases of GR and CU.

Effects of IGF-I and nutrition on phase-related growth. Individual levels of protein $(\mathrm{g} / \mathrm{kg} / \mathrm{d})$ and energy $(\mathrm{kcal} / \mathrm{kg} / \mathrm{d})$ intake in relation to PMA are given in Figure 3. Multivariate analysis to asses the effect of IGF-I and nutrition on growth during the respective growth phases was performed including independent variables, as described previously. Increased concentrations of IGF-I during phase of GR predicted independently positive change in SDS weight during both phase of GR and phase of CU but were not predictive for change in length or HC SDS (Tables 3 and 4). Nutritional intake during phase of GR was not predictive for change in SDS for any of the growth parameters, whereas increased protein and energy intake independently predicted positive change in weight and 

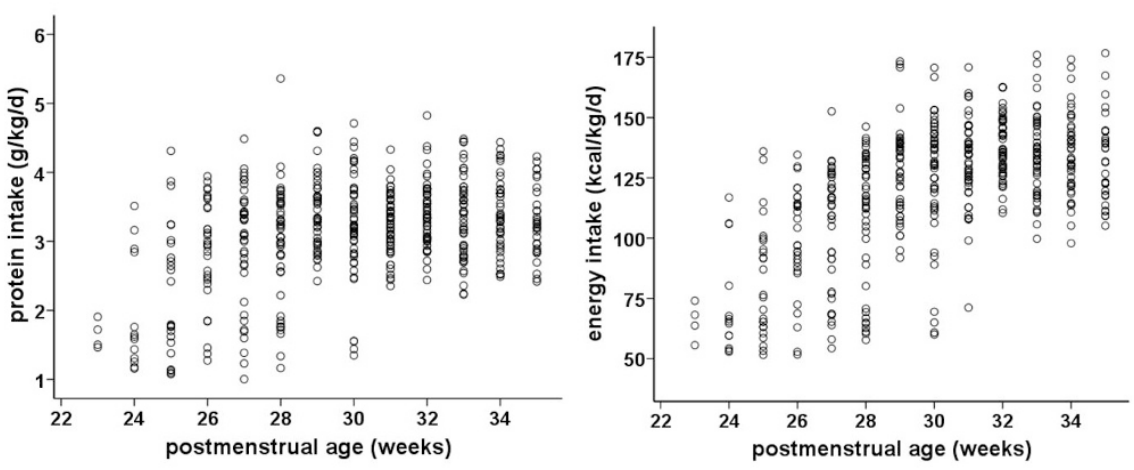

Figure 3. Individual levels of protein $(\mathrm{g} / \mathrm{kg} / \mathrm{d})$ and caloric intake $(\mathrm{kcal} / \mathrm{kg} / \mathrm{d})$ in relation to PMA.

Table 3. Stepwise regression analysis of variables contributing to change in SDS weight during phase of GR with protein and energy intake evaluated in separate models

\begin{tabular}{|c|c|c|c|c|c|}
\hline \multicolumn{3}{|c|}{ Energy intake* } & \multicolumn{3}{|c|}{ Protein intake $\dagger$} \\
\hline Variable & Beta & $p$ & Variable & Beta & $p$ \\
\hline GA & 0.085 & $<0.001$ & GA & 0.085 & $<0.001$ \\
\hline BW & -0.003 & $<0.001$ & BW & -0.003 & $<0.001$ \\
\hline IGF-I & 0.037 & 0.001 & IGF-II & 0.038 & 0.001 \\
\hline Female gender & -0.303 & 0.004 & Female gender & -0.295 & 0.004 \\
\hline
\end{tabular}

Variables included in models are GA, gender, BW, duration of GR phase (wk), mean IGF-I ( $\mu \mathrm{g} / \mathrm{L})$, accumulated protein $(\mathrm{g})$ and energy intake (kcal), accumulated dose of hydrocortisone and betamethasone $(\mathrm{mg} / \mathrm{kg}$ ), and accumulated dose of insulin $(\mathrm{E} / \mathrm{kg})$ during phase of GR for weight.

$* R^{2}=0.77 ;$ Adj $R^{2}=0.75$.

$\dagger R^{2}=0.77 ;$ Adj $R^{2}=0.75$.

Table 4. Stepwise regression analysis of variables contributing to change in SDS weight during phase of $C U$ with protein and energy intake evaluated in separate models

\begin{tabular}{|c|c|c|c|c|c|}
\hline \multicolumn{3}{|c|}{ Energy intake* } & \multicolumn{3}{|c|}{ Protein intake $\dagger$} \\
\hline Variable & Beta & $p$ & Variable & Beta & $p$ \\
\hline IGF-I & 0.02 & 0.004 & IGF-I & 0.016 & 0.027 \\
\hline Energy intake & 0.0002 & $<0.001$ & Protein intake & 0.006 & $<0.001$ \\
\hline
\end{tabular}

Variables included in models are GA, gender, BW, duration of CU phase $(w \mathrm{k})$, mean IGF-I ( $\mu \mathrm{g} / \mathrm{L})$, accumulated protein $(\mathrm{g})$ and energy intake (kcal), and accumulated dose of hydrocortisone and betamethasone $(\mathrm{mg} / \mathrm{kg})$ during phase of $\mathrm{CU}$ for weight.

$* R^{2}=0.45$; Adj $R^{2}=0.43$.

$\dagger R^{2}=0.44 ;$ Adj $R^{2}=0.41$.

HC SDS during phase of CU but not for change in length SDS (Tables 4 and 5).

Effect of nutrition on levels of IGF-I in relation to PMA. Correlations between accumulated protein and energy intakes during each separate GW (GW 24-35) and concentrations of IGF-I obtained at the end of the corresponding GW were evaluated. Nutritional regime and the resulting intake relative to body weight are based on postnatal age. This was adjusted for by including GA at birth as an independent variable. Protein intake $(\mathrm{g} / \mathrm{kg} / \mathrm{wk})$ at a PMA of 32,33 , and $34 \mathrm{wk}$ correlated to concentrations of IGF-I, $(p=0.002, p<0.001$, and $p=0.014)$. Caloric intake (kcal/kg/wk) at a PMA of 32, 34 , and 35 correlated to concentrations of IGF-I ( $p=0.015$, $p=0.023$, and $p=0.023$ ). Thus, significant correlations between nutritional intake and concentrations of IGF-I were only present during phase of CU and not during phase of GR.
Table 5. Stepwise regression analysis of variables contributing to change in SDS HC during phase of $C U$ with protein and energy intake evaluated in separate models

\begin{tabular}{|c|c|c|c|c|c|}
\hline \multicolumn{3}{|c|}{ Energy intake* } & \multicolumn{3}{|c|}{ Protein intake $\dagger$} \\
\hline Variable & Beta & $p$ & Variable & Beta & $p$ \\
\hline Energy intake & 0.001 & 0.015 & Protein intake & 0.003 & 0.048 \\
\hline \multicolumn{6}{|c|}{$\begin{array}{l}\text { Variables included in models are GA, gender, BW, duration of CU phase } \\
\text { (wk), mean IGF-I ( } \mu \mathrm{g} / \mathrm{L}) \text {, accumulated protein }(\mathrm{g}) \text { and energy intake }(\mathrm{kcal}) \text {, } \\
\text { and accumulated dose of hydrocortisone and betamethasone }(\mathrm{mg} / \mathrm{kg}) \text { during } \\
\text { phase of CU for HC. } \\
\quad * R^{2}=0.13 \text {; Adj } R^{2}=0.11 \text {. } \\
\quad \dagger R^{2}=0.09 \text {; Adj } R^{2}=0.07 \text {. }\end{array}$} \\
\hline
\end{tabular}

\section{DISCUSSION}

Our main findings were A) nutrient intake had no modifying effect on measures of growth or on circulating levels of IGF-I during the initial phase of GR, whereas B) nutrient intake modified growth and circulating levels of IGF-I during the subsequent phase of $\mathrm{CU}$ growth. On the other hand, levels of IGF-I were associated with growth during both phases. C) Longitudinal changes in circulating levels of IGF-I coincided with a predictable transition from GR to $\mathrm{CU}$ growth appearing at $30 \mathrm{GW}$.

Phases of postnatal growth. The calculation of SDS for prospectively registered weight, length, and $\mathrm{HC}$ data from birth until $35 \mathrm{GW}$ enabled a separated evaluation of the influence of variables associated with growth during two characteristic phases, i.e. the phase of GR and that of CU. Lowest SDS for all growth parameters occurred at a postnatal GA of $\sim 30$ wk independently of GA at birth. Similar observations have been described previously for HC SDS (19). The consistent finding of a nadir occurring at a similar postnatal GA in the majority of infants suggests either a switch in concentrations of endogenous factors important for postnatal growth and/or an improved utilization of nutritional intake at this time point of gestation.

The duration of GR phase was prolonged for the most immature infants, and these infants also experienced a more pronounced decrease in SDS. These differences were not explained by a lower accumulated nutritional intake in the infants with lowest GA (data not shown). Increased extrauterine GR with decreasing GA has been described earlier (20).

Growth-restricted infants (weight, length, or HC SDS $<-2$ SDS at birth) had a less pronounced postnatal decrease in SDS, which was not explained by GA or nutritional intake 
(data not shown). However, these infants had significantly lower SDS at 35 and $40 \mathrm{GW}$ compared with infants with appropriate growth at birth (data not shown). This indicates an insufficient $\mathrm{CU}$ which is in line with other studies (1). In addition, mean concentrations of IGF-I were lower during both GR and $\mathrm{CU}$ phases for infants growth restricted in weight, length, or $\mathrm{HC}$ at birth compared with infants with appropriate growth.

Postnatal treatment with dexamethasone has negative effects on longitudinal growth in preterm infants and has been associated with a decrease in IGF-I concentrations $(21,22)$. In this study, intake of hydrocortisone or betamethasone was neither associated with decreased growth nor with reduced mean concentrations of IGF-I after adjustment for GA at birth. Insulin is an important fetal growth factor and regulates production of IGF-I (23). Administered insulin prevents weight loss in very preterm infants (24). Only a minority of the infants in this study received insulin and we failed to detect any correlation with degree of growth.

Longitudinal IGF-I and postnatal growth. Mean concentrations of IGF-I were considerably lower than reported mean intrauterine concentrations during corresponding $\mathrm{GW}$, with a sharp increase appearing at a GA of $30 \mathrm{wk}$ and onward. Intrauterine IGF-I concentrations increase gradually during pregnancy, but in a more linear pattern (25). Similar findings with low postnatal IGF-I concentrations after preterm birth have been described $(11,15,26)$. Of note, the time point for the postnatal surge in IGF-I concentrations parallelled the beginning of CU in SDS for all growth parameters suggesting an association between these events.

Several studies have described positive correlations between circulatory concentrations of IGF-I and postnatal growth (12-14). We found that IGF-I had a positive modifying effect on change in weight SDS in both growth phases but did not find any corresponding effect of IGF-I for $\mathrm{HC}$ or length. This discrepancy is supported by another study where change in total IGF-I in preterm infants during a period of 4 wk was a positive predictor for postnatal weight gain but not for corresponding length or HC data (27).

Nutritional intake and growth. An optimal nutritional intake is a requisite for adequate postnatal growth. Weight gain is principally based on energy intake, whereas length and $\mathrm{HC}$ growth are more influenced by protein intake (28). The contribution of protein and energy intake was thus evaluated separately in multivariate models. Early nutritional intake has been shown to predict early postnatal weight gain in extremely preterm infants $(29,30)$, whereas other studies did not show any predictive capacity of nutrition in multivariate models $(12,27)$.

In our study, nutritional intake had a positive effect on change in SDS weight and HC SDS, but the effect was only observed during the phase of CU. The nutritional policy in our unit follows current recommendations, with a gradual increase of administered protein and energy intake from birth and onward. Thus, an optimal nutritional intake according to intrauterine requirements (minimum protein $3.5 \mathrm{~g} / \mathrm{kg} / \mathrm{d}$ and energy $120 \mathrm{kcal} / \mathrm{kg} / \mathrm{d}$ ) was not achieved until after 2 wk of postnatal age (data not shown). Nutritional intake in relation to GA, as shown in Figure 2, increased up until 29-30 wk and remained unchanged thereafter.
This pattern coincides with the observed transition from GR to CU growth. Importantly, variation in nutritional intake had no effect on degree of GR, which suggests that optimization of protein and caloric intake alone would not efficiently suffice in prevention of postnatal GR.

IGF-I and nutritional intake. Infusion of glucose but not amino acids regulates concentrations of IGF-I in fetal sheep (31). In preterm infants, both protein and energy intake have been demonstrated to have a positive effect on IGF-I concentrations $(14,32)$. We found that a positive correlation between IGF-I and nutritional intake was restricted to the period beyond $30 \mathrm{GW}$. In line with this, we found that both protein and energy intake were positively associated with change in weight and HC SDS during the CU phase, whereas no effect of nutritional intake was observed during the initial GR phase. This indicates that variations in nutritional intake have a lesser impact on endogenous IGF-I concentrations during the lowest GW. Influence of protein intake on circulatory levels of IGF-I has been shown to increase with increased GA and postnatal age (32).

IGF-I has been shown to be protective for the brain after undernutritional insults in experimental studies in mice (33). Further IGF-I infusion to fetal sheep results in anabolic effects with increased transplacental amino acid and glucose uptake and decreased fetal protein breakdown $(34,35)$. In a recent study in mice, administration of IGF-I was associated with higher weight gain and higher endogenous IGF-I levels (36). Thus, hypothetically an increase in IGF-concentrations during the early postnatal period when undernutrition is more or less present may be of benefit for a better utilization of nutrients and for neural protection.

In conclusion, circulatory IGF-I concentrations but not nutritional intake are associated with growth in the immediate postnatal period after birth. The common temporal appearance of a positive change in SDS growth curve with the postnatal surge in IGF concentrations, and the positive correlation between IGF-I and nutritional intake, suggests an interaction between these events. Whether treatment aiming at increasing circulatory IGF-I concentrations will improve postnatal growth in very preterm infants remains to be studied.

Acknowledgments. We thank Ann-Cathrine Berg and Eva Hammarstrand for excellent help with retrieving data for the study and Ann Forsberg and Susanne Bach-Meineche for assistance in performing growth measurements.

\section{REFERENCES}

1. Pilling EL, Elder CJ, Gibson AT 2008 Growth patterns in the growth-retarded premature infant. Best Pract Res Clin Endocrinol Metab 22:447-462

2. Cheong JL, Hunt RW, Anderson PJ, Howard K, Thompson DK, Wang HX, Bear MJ, Inder TE, Doyle LW 2008 Head growth in preterm infants: correlation with magnetic resonance imaging and neurodevelopmental outcome. Pediatrics 121:e1534-e1540

3. Ehrenkranz RA, Dusick AM, Vohr BR, Wright LL, Wrage LA, Poole WK 2006 Growth in the neonatal intensive care unit influences neurodevelopmental and growth outcomes of extremely low birth weight infants. Pediatrics 117:1253-1261

4. Embleton NE, Pang N, Cooke RJ 2001 Postnatal malnutrition and growth retardation: an inevitable consequence of current recommendations in preterm infants? Pediatrics 107:270-273

5. Wilson DC, Cairns P, Halliday HL, Reid M, McClure G, Dodge JA 1997 Randomised controlled trial of an aggressive nutritional regimen in sick very low birthweight infants. Arch Dis Child Fetal Neonatal Ed 77:F4-F11 
6. Tan M, Abernethy L, Cooke R 2008 Improving head growth in preterm infants-a randomised controlled trial II: MRI and developmental outcomes in the first year. Arch Dis Child Fetal Neonatal Ed 93:F342-F346

7. Ye P, D'Ercole AJ 2006 Insulin-like growth factor actions during development of neural stem cells and progenitors in the central nervous system. J Neurosci Res $83: 1-6$

8. Holt RI 2002 Fetal programming of the growth hormone-insulin-like growth factor axis. Trends Endocrinol Metab 13:392-397

9. Han VK, Bassett N, Walton J, Challis JR 1996 The expression of insulin-like growth factor (IGF) and IGF-binding protein (IGFBP) genes in the human placenta and membranes: evidence for IGF-IGFBP interactions at the feto-maternal interface. J Clin Endocrinol Metab 81:2680-2693

10. Hansen-Pupp I, Hellstrom-Westas L, Cilio C, Andersson S, Fellman V, Ley D 2007 Inflammation at birth and the insulin-like growth factor system in very preterm infants. Acta Paediatr 96:830-836

11. Lineham JD, Smith RM, Dahlenburg GW, King RA, Haslam RR, Stuart MC, Faull L 1986 Circulating insulin-like growth factor I levels in newborn premature and full-term infants followed longitudinally. Early Hum Dev 13:37-46

12. Kajantie E, Dunkel L, Rutanen EM, Seppala M, Koistinen R, Sarnesto A, Andersson S 2002 IGF-I, IGF binding protein (IGFBP)-3, phosphoisoforms of IGFBP-1, and postnatal growth in very low birth weight infants. J Clin Endocrinol Metab 87:21712179

13. Ohkawa N, Shoji H, Kitamura T, Suganuma H, Yoshikawa N, Suzuki M, Lee T, Hisata K, Shimizu T 2010 IGF-I, leptin and active ghrelin levels in very low birth weight infants during the first 8 weeks of life. Acta Paediatr 99:37-41

14. Engström E, Niklasson A, Wikland KA, Ewald U, Hellstrom A 2005 The role of maternal factors, postnatal nutrition, weight gain, and gender in regulation of serum IGF-I among preterm infants. Pediatr Res 57:605-610

15. Hellström A, Engstrom E, Hard AL, Albertsson-Wikland K, Carlsson B, Niklasson A, Lofqvist C, Svensson E, Holm S, Ewald U, Holmstrom G, Smith LE 2003 Postnatal serum insulin-like growth factor I deficiency is associated with retinopathy of prematurity and other complications of premature birth. Pediatrics 112:10161020

16. Marsál K, Persson PH, Larsen T, Lilja H, Selbing A, Sultan B 1996 Intrauterine growth curves based on ultrasonically estimated foetal weights. Acta Paediatr 85:843-848

17. Blum WF, Breier BH 1994 Radioimmunoassays for IGFs and IGFBPs. Growth Regul 4:11-19

18. Niklasson A, Albertsson-Wikland K 2008 Continuous growth reference from 24th week of gestation to 24 months by gender. BMC Pediatr 8:8

19. Löfqvist C, Engstrom E, Sigurdsson J, Hard AL, Niklasson A, Ewald U, Holmstrom G, Smith LE, Hellstrom A 2006 Postnatal head growth deficit among premature infants parallels retinopathy of prematurity and insulin-like growth factor-1 deficit. Pediatrics 117:1930-1938

20. Clark RH, Thomas P, Peabody J 2003 Extrauterine growth restriction remains a serious problem in prematurely born neonates. Pediatrics 111:986-990
21. Bloomfield FH, Knight DB, Breier BH, Harding JE 2001 Growth restriction in dexamethasone-treated preterm infants may be mediated by reduced IGF-I and IGFBP-3 plasma concentrations. Clin Endocrinol (Oxf) 54:235-242

22. Gibson AT, Pearse RG, Wales JK 1993 Growth retardation after dexamethasone administration: assessment by knemometry. Arch Dis Child 69:505-509

23. Bereket A, Lang CH, Blethen SL, Gelato MC, Fan J, Frost RA, Wilson TA 1995 Effect of insulin on the insulin-like growth factor system in children with new-onset insulin-dependent diabetes mellitus. J Clin Endocrinol Metab 80:1312-1317

24. Beardsall K, Vanhaesebrouck S, Ogilvy-Stuart AL, Vanhole C, Palmer CR, van Weissenbruch M, Midgley P, Thompson M, Thio M, Cornette L, Ossuetta I, Iglesias I, Theyskens C, de Jong M, Ahluwalia JS, de Zegher F, Dunger DB 2008 Early insulin therapy in very-low-birth-weight infants. N Engl J Med 359:1873-1884

25. Langford K, Nicolaides K, Miell JP 1998 Maternal and fetal insulin-like growth factors and their binding proteins in the second and third trimesters of human pregnancy. Hum Reprod 13:1389-1393

26. Hikino S, Ihara K, Yamamoto J, Takahata Y, Nakayama H, Kinukawa N, Narazaki Y, Hara T 2001 Physical growth and retinopathy in preterm infants: involvement of IGF-I and GH. Pediatr Res 50:732-736

27. Lo HC, Tsao LY, Hsu WY, Chi CY, Tsai FA 2005 Changes in serum insulin-like growth factors, not leptin, are associated with postnatal weight gain in preterm neonates. JPEN J Parenter Enteral Nutr 29:87-92

28. Sauer PJ 2007 Can extrauterine growth approximate intrauterine growth? Should it? Am J Clin Nutr 85:608S-613S

29. Martin CR, Brown YF, Ehrenkranz RA, O'Shea TM, Allred EN, Belfort MB, McCormick MC, Leviton A 2009 Nutritional practices and growth velocity in the first month of life in extremely premature infants. Pediatrics 124:649-657

30. Olsen IE, Richardson DK, Schmid CH, Ausman LM, Dwyer JT 2002 Intersite differences in weight growth velocity of extremely premature infants. Pediatrics 110:1125-1132

31. Oliver MH, Harding JE, Breier BH, Evans PC, Gluckman PD 1993 Glucose but not a mixed amino acid infusion regulates plasma insulin-like growth factor-I concentrations in fetal sheep. Pediatr Res 34:62-65

32. Smith WJ, Underwood LE, Keyes L, Clemmons DR 1997 Use of insulin-like growth factor I (IGF-I) and IGF-binding protein measurements to monitor feeding of premature infants. J Clin Endocrinol Metab 82:3982-3988

33. Ye P, Lee KH, D'Ercole AJ 2000 Insulin-like growth factor-I (IGF-I) protects myelination from undernutritional insult: studies of transgenic mice overexpressing IGF-I in brain. J Neurosci Res 62:700-708

34. Harding JE, Liu L, Evans PC, Gluckman PD 1994 Insulin-like growth factor 1 alters feto-placental protein and carbohydrate metabolism in fetal sheep. Endocrinology 134:1509-1514

35. Liechty EA, Boyle DW, Moorehead H, Lee WH, Yang XL, Denne SC 1999 Glucose and amino acid kinetic response to graded infusion of rhIGF-I in the late gestation ovine fetus. Am J Physiol 277:E537-E543

36. Vanhaesebrouck S, Daniels H, Moons L, Vanhole C, Carmeliet P, De Zegher F 2009 Oxygen-induced retinopathy in mice: amplification by neonatal IGF-I deficit and attenuation by IGF-I administration. Pediatr Res 65:307-310 